\title{
Palm sugar business management and its contribution towards household revenues in Lebak District, Banten
}

\author{
AAstuti $^{1}$, RM Sari $^{{ }^{*}}$ and A Mulyaningsih $^{1}$ \\ ${ }^{1}$ Agribusiness Department, Faculty of Agriculture, University of Sultan Ageng \\ Tirtayasa
}

*Corresponding author: ratna.megasari@untirta.ac.id

\begin{abstract}
This study aims to identify palm sugar business characteristic, to analyze the allocation of labor and household revenue of palm sugar craftsmen and to analyze the contribution of palm sugar income to the craftsmen household in Lebak Regency. The research data used were primary data and secondary data which were processed descriptively and quantitatively. Sampling was carried out randomly (simple random sampling) in five sub-districts of palm sugar centers in Lebak Regency. The results showed that the average palm sugar craftsman allocated his time of 6.66 hours per day to produce palm sugar. The allocation of labor is distributed in several stages of the production process including tapping, cooking, stirring, printing and drying. As much as $77.14 \%$ of the total household income of palm sugar craftsmen comes from the palm sugar business. Other income is obtained from farming other commodities and trading. Total income is allocated for food expenditure, non-food expenditure and savings. Expenditures on food account for $60 \%$ of total expenditure, while non-food expenditures are 32 percent and savings are 8 percent.
\end{abstract}

\section{Introduction.}

The development of the local economy through the home industry sector has a great influence on the national economy. Apart from providing support in the economic aspect, this industry also plays a strategic role in the development of potential local commodities. One of the leading local commodities that can become a national mainstay is palm sugar

Palm sugar is a derivative product of palm plants. Before being processed into palm sugar, the raw material that comes from the palm plant is called sap. Nira is a sweet liquid obtained from bunches of sugar palm plants. Palm sugar can be used as an additive or flavoring in the food industry such as making soy sauce and lunkhead, additives or flavorings in processed foods such as cakes, compote, and other food preparations, as well as sweetening ingredients in beverages such as bandrek, bajigur, coffee, and others.

Palm sugar has its own peculiarities when compared to sugar from other sources. The peculiarities of this product include, it dissolves more easily, is dry and clean and has a distinctive aroma. This peculiarity causes palm sugar to be widely used to make cakes, soy sauce and other food products [1]. According to [5] the excess of palm sugar compared to other sugars is based on chemical composition, which is a higher sucrose content, namely 84.81 percent compared to coconut sugar 71.89 percent and 
palm sugar 76.86 percent, so that palm sugar is able to provide higher energy than coconut sugar and siwalan sugar.

Based on its nutritional content, compared to other sugars, palm sugar contains higher protein and phosphorus than coconut sugar and palm sugar. Palm sugar also contains low fat compared to sugar derived from coconut sugar and palm sugar. High protein content and low fat content indicate that palm sugar is better for consumption than sugar derived from coconut and palm, especially for health benefits.

Banten is one of the centers for palm sugar production in Indonesia [3]. The growth of palm sugar production in Banten Province has a positive trend. Palm sugar production from 2009 to 2011 experienced an increasing trend, while in 2012 there was a decrease in production by 0.24 percent. This is due to declining of productivity, and season change. Meanwhile, in 2013 the production had increased again by 0.60 percent. However, the growth of palm sugar production in Banten Province for five years from 2009 to 2013 increased by an average of 0.09 percent every year. This shows that the growth of palm sugar production is very slow, because there is no government support in palm sugar nurseries.

Palm sugar centers in Banten Province are located in the some Regencies [4] . The growth of palm sugar production in Lebak Regency has an average positive trend. Palm sugar production experienced a steady growth from 2009 to 2010 , but experienced a decline in 2011 amounting to 81.32 percent, production again increased in 2012 with the highest figure of 523.38 percent. Meanwhile, in 2013 it experienced another decline of 12.63 percent. This is because there are plants that have experienced a decline in productivity, plants that are no longer productive, and seasons change.

Meanwhile, the growth of palm sugar production in Lebak Regency for five years from 2009 to 2013 increased by an average of 0.35 percent each year. The growth of palm sugar production in Lebak Regency is relatively fast. Lebak Regency has contributed 70 percent of palm sugar in Banten for the last five years. Meanwhile for the last year 2013, Lebak contributed palm sugar in Banten, namely 81 percent. This shows that Lebak Regency plays a major role in supplying palm sugar in Banten.

The palm sugar production areas in Lebak Regency are spread over 28 districts and the centers are in 15 Districts. Palm sugar producing areas include Sobang, Bojong Manik, Lebak Gedong, Sajira, Gunung Kencana, Cigemblong, Cijaku, Cibeber, Cilograng, Cihara, Muncang, Cirinten, Wanassalam, Malingping and Panggarangan Districts. The amount of palm sugar production in production centers is 12082.35 tons per year. The biggest producer is in Sobang District with a percentage of 21 percent (2505.3 tons per year). All of The palm sugar produced in these districts includes printed palm sugar and ants palm sugar.

Based on the description above, the purposes of this study are to identify palm sugar business characteristic, to analyze allocation of labor and craftsmen household income in the management of palm sugar business, to analyze contribution of palm sugar income to the household income of craftsmen in Lebak Regency, Banten.

\section{Methods}

The research was conducted using a survey method. The location of the research was determined purposively with the consideration that Lebak Regency is the center for palm sugar production in Banten Province. Data of Palm sugar Business management was obtained from observation, literature review, interview and questioners written as qualitative descriptive. Craftsmen Household Income is amount of palm sugar income and non-palm sugar income. The formula used to calculate :

$$
T P=P 1+P 2
$$

Description.

$\mathrm{TP}=$ Total of Househol Income

P1 = Palm Sugar Income 
P2 =Non Palm Sugar Income

Contribution of palm sugar income to household income was obtained from comparison of palm sugar income and total of household income and was multipled by 100 percent. Formula used is

$$
K P=\frac{P 1}{T P} x 100 \%
$$

KP : Contribution of palm sugar income to household income

P1 : Palm Sugar Income

P2 : non palm sugar income

\section{Result and Discusion}

\subsection{Palm sugar business Characteristic in Lebak District}

Aren trees that grow in Lebak Regency are generally not planted and cultivated intentionally. A selfgrowing population of palm trees which is spread naturally by civets. Palm trees are owned in units of the number of trees per household.

All respondents of palm sugar are male with an age range from 35 - 61 years. The average age of craftsmen was 46 years. This shows that the management of palm sugar business is carried out at a range of ages that are still productive. Mubyarto (1989) explains that the productive age ranges from 15 - 65 years which will result in maximum work productivity.

The level of education of palm sugar craftsmen in Lebak Regency varies greatly from not attending school to graduating from high school. 11.76 percent of respondents stated that they had never received formal education, 5.88 percent graduated from elementary school, 7.84 percent graduated from junior high school and 74.51 percent graduated from high school. This data shows that the level of education for palm sugar craftsmen is quite good because more than 70 percent of the craftsmen are high school graduates. Business experience ranges from 1-8 years with an average business experience of 4 years.

Palm sugar craftsmen have good education in average. 70 percent of palm sugar craftsmen graduated from high school education. This condition is important capital to improve the craftsmen skill. Good education will be a good capital to conduct empowerment.

\subsection{Labor Allocation of Palm Sugar Business in Lebak Regency}

The palm sugar craftsmen spend 6-12 hours on the management of the palm sugar business. The average time spent by the respondents was 6.66 hours divided into several production stages, namely tapping, cooking, stirring, printing and drying. This time is the remaining time because their main time is spent doing main work. The main jobs of craftsmen vary, including traders, farming and entrepreneurship. Palm sugar production is carried out for thirty days a month which means that the craftsmen try to maintain the continuity of the palm sugar they produce. This is a good non-material capital in a business besides quantity and quality.

The income of palm sugar craftsmen varies between 45,000 - 320,000 per day. This really depends on the amount of sap that can be tapped by the craftsman. This income will later be allocated back into production capital which includes production costs. Production costs are divided into variable costs and fixed costs. The variable cost is the cost of purchasing raw materials for the production process, namely whiting and firewood. Fixed costs are simply depreciation costs for the equipment used. The equipment commonly used are pans, axes, machetes, printing tools, jerry cans, basins, filters, hammers, silk, furnaces, stirrers, scoop tools and lodong (tapping tools).

\subsection{Contribution of Palm Sugar Business Towards Craftsmen Income In Lebak District}


The contribution of palm sugar business to craftsmen household income is the ratio between palm sugar business income and the total income owned by the household. Based on the research results, it is found that palm sugar business income is in the range of 450,000 to 5400,000 where the average income is Rp. 2,230,200. The average contribution of income is 77.14 percent and the rest is income from non-sugar palm businesses which include trading, farming, agricultural labor and others (Figure $1)$.

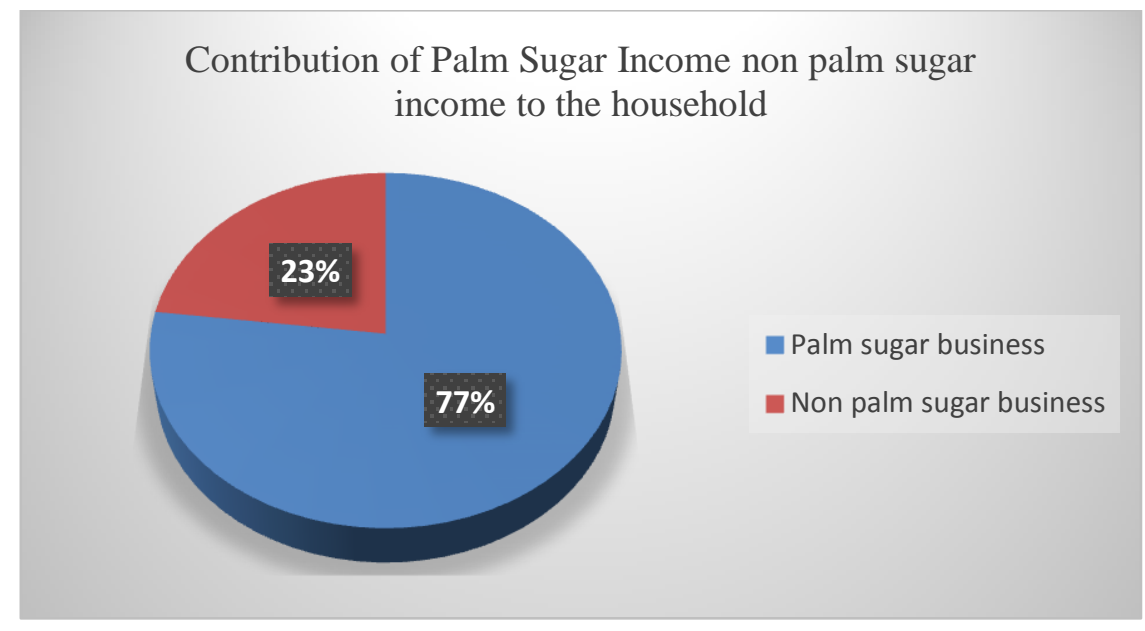

Figure 1. Contribution of Palm Sugar and Non Palm Sugar Income to the household

Palm sugar craftsmen household income is distributed in several post (Figure 1), namely food expenditure, non-food expenditure and savings. The average food expenditure that the craftsman household consumes every month is Rp. 1,736,000, the average non-food expenditure is Rp. 928,000 and the average savings per craftsman household is Rp. 227,000.

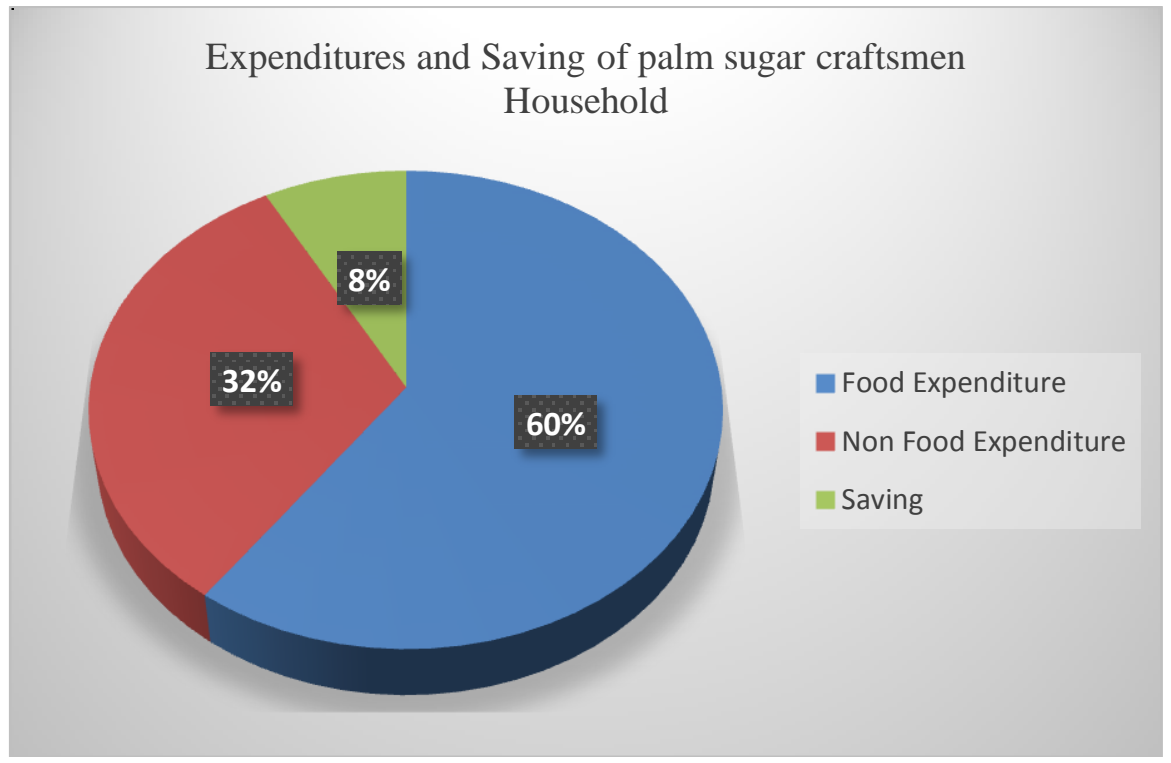

Figure 2. Expenditures and Saving of palm sugar craftsmen

Result of research show that most of craftsmen's expenditure is food which is 60 percent. It indicates that household income is still low. It also shows the food security condition of craftsmen household. [2,6] stated that food expenditure share is one of indicators of food security. The more of 
food expenditure share, the less of food security level of household. Thus the welfare of craftsmen must be improved. Government should pay more attention related to this condition.

\section{Conclusion}

The results showed that the average palm sugar craftsman allocated his time of 6.66 hours per day to produce palm sugar. The allocation of labor is distributed in several stages of the production process including tapping, cooking, stirring, printing and drying. As much as $77.14 \%$ of the total household income of palm sugar craftsmen comes from the palm sugar business. Other income is obtained from farming other commodities and trading. Total income is allocated for food expenditure, non-food expenditure and savings. Expenditures on food account for $60 \%$ of total expenditure, while non-food expenditures are 32 percent and savings are 8 percent.

\section{References}

[1] Aliudin. 2010. Prospek Gula Aren dalam Agroindustri. Bandung (ID): Unpad Press. Amir IT.

[2] Azwar, A. 2004. Aspek Kesehatan dan Gizi dalam Ketahanan Pangan. Dalam: Prosiding Widyakarya Nasional Pangan Dan Gizi VIII "Ketahanan Pangan dan Gizi di Era Otonomi Daerah dan Globalisasi". BPS, Departemen Kesehatan, Badan POM, Bappenas, Departemen Pertanian dan Ristek, Jakarta.

[3] [BI] Bank Indonesia. 2009. Pola Pembiayaan Usaha Kecil Syariah (PPUK) Gula Aren (Gula Semut dan Gula Cetak). Jakarta (ID): Bank Indonesia.

[4] [BPS] Badan Pusat Statistik Kabupaten Lebak. 2010-2014. Lebak dalam Angka 2009-2013. Lebak (ID): BPS Kabupaten Lebak.

[5] Rumokoi, M.M.M. 1990. Manfaat tanaman aren (Arenga pinnata Merr). Buletin Balitka No.10 Thn 1990 hal: 21-28. Balai Penelitian Kelapa, Manado.

[6] Suhardjo.1996. Pengertian dan Kerangka Pikir Ketahanan Pangan Rumah Tangga. Makalah disampaikan pada Lokakarya Ketahanan Pangan Rumah Tangga, 20-30 May 1996. Yogyakarta 